\title{
Sosialisasi Sekolah Ramah Anak Pada MAN Malakaji di Kabupaten Gowa Sulawesi Selatan
}

\author{
Najamuddin ${ }^{1}$, Bustan $^{2}$, Hasni $^{3}$ \\ ${ }^{1}$ Jurusan Pendidikan Sejarah, Fakultas Ilmu sosial, Universitas Negeri Makassar \\ ${ }^{2}$ Jurusan Pendidikan Sejarah, Fakultas Ilmu Sosial, Universitas Negeri Makassar \\ ${ }^{3}$ Jurusan Pendidikan Ilmu Pengetahuan Sosial, Fakultas Ilmu Sosial, Universitas Negeri Makassar
}

\begin{abstract}
This Community Partnership Program (PKM) partner is the Socialization of Child Friendly Schools in MAN Malakaji, Gowa Regency, South Sulawesi. The problems are: (1) The stakeholders' lack of awareness to work together to create child-friendly schools. (2) Teachers still do not understand in detail the concepts and programs of Child-Friendly Schools, so their implementation is still not effective. The methods used are: lectures, demonstrations, discussions, questions and answers with colleagues through the Zoom Meeting application. The results achieved were (1) partners were very enthusiastic about the socialization, marked by the number of participants and questions asked, (3) partners really needed socialization and understanding of Child Friendly Schools which was shown by the spirit of participation and curiosity, (4) Quality improvement understanding and mastery is ensured. contrary to the concept of the Child-Friendly School Program (SRA).
\end{abstract}

Keywords: Socialization, Child Friendly School, MAN Malakaji.

\section{PENDAhuluan}

Program Kemitraan Masyarakat (PKM) yang telah dilaksanakan bermitra dengan MAN Malakaji Kabupaten Gowa. Jl. Mesjid Raya No. 1 Malakaji Kabupaten Gowa, Sulawesi Selatan.

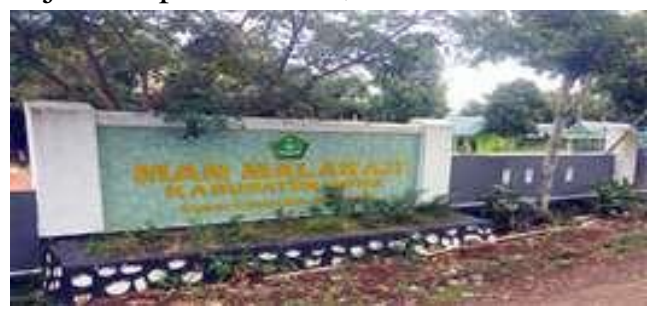

Gambar 1.Sekolah Mitra PKM

Kondisi UKM mitra sebagai berikut:

Sekolah ramah anak ini bisa terwujud apabila pemangku kepentingan pendidikan bahu-membahu melakukan penguatan lingkungan sekolah dan lingkungan kelas yang dapat memengaruhi rasa aman serta nyaman. Undang-undang Nomor 20 tahun 2003 mengamanatkan, pendidikan adalah usaha sadar dan terencana untuk mewujudkan suasana belajar serta proses pembelajaran agar peserta didik secara aktif mengembangkan potensi dirinya untuk memiliki kekuatan spiritual keagamaan, pengendalian diri, kepribadian, kecerdasan, akhlak mulia, serta keterampilan yang diperlukan dirinya, masyarakat, bangsa dan negara.

Suasana yang diharapkan adalah suasana yang mendukung terjadinya proses pendidikan yang bisa mengembangkan potensi peserta didik mampu mengembangkan minat, bakat dan kemampuan anak, serta mempersiapkan anak untuk bertanggung jawab kepada kehidupan yang toleran, saling menghormati, dan bekerja sama untuk kemajuan serta semangat perdamaian.

Kenyataannya suasana belajar saat ini belum sesuai harapan. Perlindungan Perempuan dan Anak Indonesia (PPAI) mencatat $84 \%$ siswa pernah mengalami kekerasan di sekolah, 75\% siswa mengakui pernah melakukan kekerasan di sekolah, 45\% siswa laki-laki menyebutkan bahwa guru atau petugas sekolah yang melakukan kekerasan, 22\% siswa perempuan menyebutkan bahwa guru atau petugas sekolah yang melakukan kekerasan, $40 \%$ siswa usia 13 - 15 tahun pernah mengalami kekerasan dari teman sebayanya, 50\% anak pernah mengalami perusakan di sekolah. 


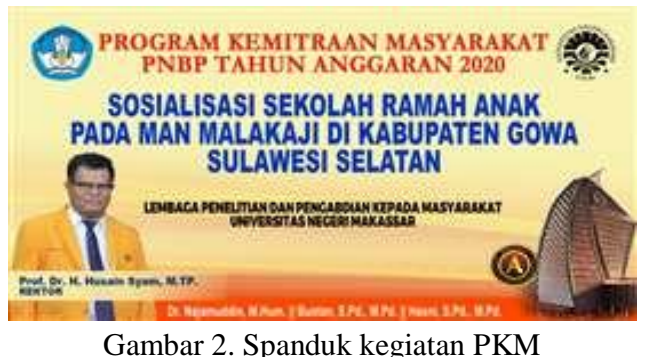

Kabupaten Gowa sebagai suatu daerah yang menerapkan sekolah ramah anak dalam penerapannya masih mengalami kesulitan. Hal tersebut disebabkan karena:

1. Masih kurangnya kesadaran pemangku kepentingan untuk bahu membahu dalam mewujudkan sekolah ramah anak

2. Para guru masih belum memahami secara detail tentang konsep ramah anak, sehingga pada pelaksanaannya kurang efektif .

Sekaitan dengan hal tersebut, Para pemangku kepentingan pendidikan seyoginya perlu bersamasama membangun kesadaran akan pentingnya proses pendidikan yang ramah dan mendukung berkembangnya potensi anak sehingga menjadi insan yang unggul dan andal. Hal ini sesuai dengan amanat Peraturan Menteri Pendidikan dan Kebudayaan Nomor 82 Tahun 2015 tetang Pencegahan dan Penanggulangan Tindak Kekerasan di Lingkungan Satuan Pendidikan. Untuk itu sekolah sebagai sebuah lembaga pendidikan diharapkan mampu menciptakan suasana belajar yang menjadi sumber inspirasi bagi anak dalam mengembangkan potensinya secara optimal di lingkungan pendidikan yang ramah pada penumbuhkembangan kreativitas.

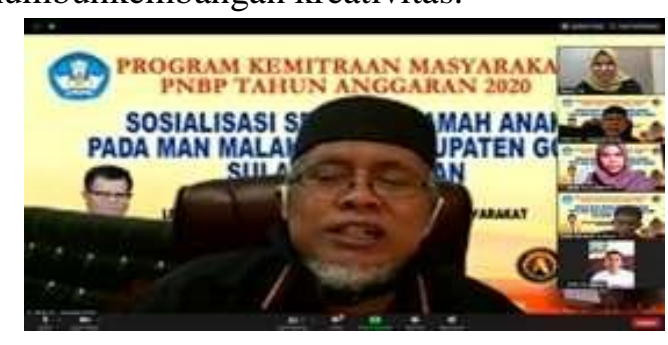

Gambar 3. Materi 1-Sosialisasi Sekolah Ramah

\section{METODE YANG DIGUNAKAN}

Adapun metode pelaksanaan yang dilakukan sebagai berikut :
1. Menyelesaikan semua urusan administrasi sebelum ke lokasi mitra yakni mengurus izin pengabdian masyarakat pada Lembaga Pengabdian Masyarakat Universitas Negeri Makassar. Izin tersebut ditujukan kepada Dinas Pendidikan Kebudayaan Kabupaten Gowa

2. Menyampaikan maksud dan tujuan sehubungan dengan pelaksanaan pelatihan guru-guru MAN Malakaji di Kabupaten Gowa

3. Tim PKM melakukan presentasi dengan materi pelatihan kepada Tim Mitra mengenai Program Sekolah Ramah Anak melalui aplikasi Zoom Meeting

4. Tim Mitra melakukan diskusi secara intensif mengenai Program Sekolah Ramah Anak dan penerapannya dalam lingkungan sekolah melalui aplikasi Zoom Meeting

5. Tim PKM bersama Tim Mitra melakukan Tanya jawab secara intensif berdasarkan hasil diskusi mengenai Program Sekolah Ramah Anak dan penerapannya dalam lingkungan sekolah melalui aplikasi Zoom Meeting.

6. Rencana kegiatan akan berlangsung selama dua minggu. Namun secara operasional jadwal kegiatan akan ditetapkan kemudian apabila telah memperoleh persetujuan kontrak Program Kemitraan Masyarakat dari Lembaga Pengabdian Masyarakat Universitas Negeri Makassar

\section{PELAKSANAAN DAN HASIL KEGIATAN}

Kegiatan ini tergolong sukses karena mendapat respon yang sangat antusias dari Tim Mitra. Kesuksesan ini tentunya tidak lepas dari peran dan pengaruh Tim Mitra yang cukup banyak menghadiri kegiatan PKM tersebut. Melihat antusiasme peserta yang begitu tinggi, membuktikan bahwa peserta memiliki motivasi yang sangat tinggi. 


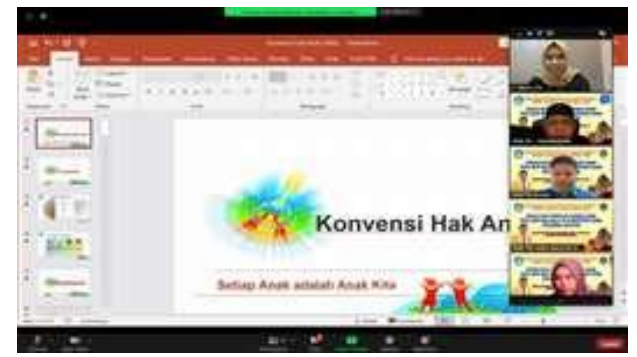

Gambar 4: Materi Konvensi Hak Anak

Berdasarkan hasil pengamatan dalam penyelenggaraan kegiatan tersebut dibuktikan dengan keaktifan peserta dalam mengemukakan pandangannya terhadap materi kajian dalam kegiatan PKM. Mereka menyadari dan mengakui bahwa materi dan kegiatan pelatihan yang diberikan kepadanya merupakan suatu kebutuhan yang sangat mendasar yang harus dimiliki oleh seorang guru Sejarah. Tentunya dengan kegiatan ini peserta merasa mendapatkan ilmu dan pengetahuan secara lengkap, detail serta sistematis terkait materi Sosialisasi Sekolah Ramah Anak pada MAN Malakaji di Kabupaten Gowa Sulawesi Selatan.

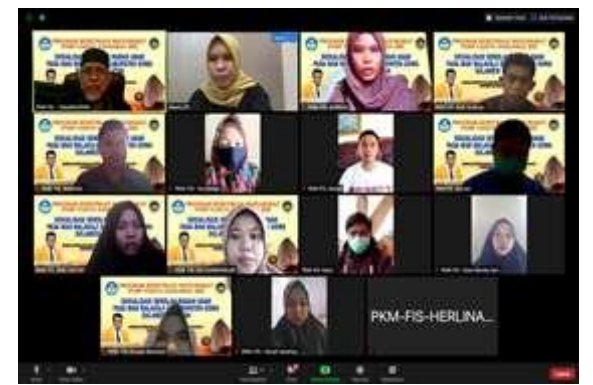

Gambar 5: Peserta sedang Mengikuti Sosialisasi

Dari hasil pantauan dan evaluasi yang dilakukan, peserta telah memiliki tingkat pemahaman yang cukup tinggi, hanya saja mereka masih membutuhkan ilmu, pengatahuan dan informasi yang lengkap, sehingga dalam memberikan materi ajar Sosialisasi Program Sekolah Ramah Anak tersebut itu bisa disampaikan secara lengkap kepada siswanya sehingga siswa bisa mengerti, memahami, serta tidak menimbulkan penafsiran yang berbeda yang dipahami oleh siswa yang dia peroleh dari informasi lain.

\section{KESIMPULAN}

Berdasarkan evaluasi yang dilakukan terhadap pelaksanaan kegiatan ini, maka dapat dikatakan bahwa kegiatan Sosialisasi Sekolah Ramah Anak (RSA) terhadap duru MAN Malakaji ini dapat dianggap berhasil. Indikator keberhasilan tersebut dapat dilihat pada beberapa hal sebagai berikut:

a. Banyaknya peserta yang menghadiri kegiatan tersebut. Disinilah kita memandang antusiasmenya guru-guru dalam mengikuti Sosialisasi Sekolah Ramah Anak pada MAN Malakaji di Kabupaten Gowa Sulawesi Selatan.

b. Antusiasme peserta yang begitu tinggi menggambarkan minat dan motivasi sehingga kegiatan semacam ini sangat dibutuhkan.

c. Diskusi dan Tanya Jawab yang dilakukan pada akhir kegiatan melalui Zoom Meeting menunjukkan perubahan yang signifikan. Ternyata pelatihan ini dapat meningkatkan kualitas, khususnya terhadap penguasaan dan pemahaman dasar tentang Sekolah Ramah Anak (SRA) sesuai dengan amanat yang harus diselenggarakan Negara untuk memenuhi hak anak sebagaimana tercantum dalam Konvensi Hak Anak yang telah di ratifikasi Indonesia pada Tahun 1990, juga adanya tuntutan dari Undang-undang Nomor 23 Tahun 2003 tentang Perlindungan Anak dan Undang-Undang Nomor 35 Tahun 2014 tentang Perubahan atas Undang-Undang Nomor 23 Tahun 2003 tentang Perlindungan Anak.

\section{UCAPAN TERIMA KASIH}

Ucapan terima kasih disampaikan kepada kepada Rektor UNM atas arahan dan pembinaanya selama proses kegiatan Pengabdian Masyarakat berlangsung, juga kepada Dekan Fakultas Ilmu Sosial yang telah memfasilitasi pendanaan PKM ini. Demikian pula ucapan terima kasih disampaikan kepada Ketua Lembaga Pengabdian Kepada Masyarakat UNM dan Pemerintah Kabupaten Gowa Provinsi Sulawesi Selatan, yang telah memberi fasilitas, melakukan monitoring, dan mengevaluasi kegiatan PKM hingga selesai.

\section{DAFTAR PUSTAKA}

Annas, Zulfikri. 2017. Sekolah untuk kehidupan. Jakarta Selatan: AMP Press 
Asa Baedowi, Ahmad dkk. 2015. Potret Pendidikan Kita. Jakarta: PT Pustaka Alvabet

Blonaco, Jodee, 2013. Bencana Sekolah. Jakarta, Pustaka Alvabet.

Dananjaya, Utomo. 2005. Sekolah Gratis Esai-Esai Pendidikan yang Memebaskan. Jakarta: Paramadina.

Emzir, 2010. Metodologi Penelitian Kualitatif, Analisis Data. Jakarta:Raja Wali Press.

Hanaco, Indah. 2012. I Love Homeschooling Segala Sesuatu Yang Harus Diketahui Tentang Homeschooling. Jakarta: PT Gramedia Pustaka Utama.

Farida, Anna dkk. 2012. Sekolah Yang Menyenangkan Metode Kreatif Mengajar dan Pengembangan Karakter Siswa. Bandung: Nuansa

Giddens, Anthony, 2009. Teori Strukturasi, Dasardasar Pembentuk Struktur Sosial Masyarakat, Yogyakarta, Pustaka Pelajar.

Kristanto. 2011. "Identifikasi Model Sekolah Ramah Anak (SRA) Jenjang Satuan Pendidikan Anak Usia Dini se-Kecamatan Semarang Selatan". Jurnal. Semarang: Paudia,

Martono Nanang. 2012. Kekerasan Sombolik di Sekolah sebuah Ide Sosiologi Pendidikan Pierre Bourdieu. Jakarta: PT. Raja Grafindo Persada

------- 2017. Sekolah Public Vs Sekolah Privat. Jakarta: Yayasan Pustaka Obor Indonesia Anggota IKAPI DKI Jakarta

Muitasari, Siti. 2016. "Implementasi Program Sekolah Ramah Anak Dalam Mengembangkan Kecakapan Hidup (Studi Pendampingan Anak Korban Kekerasan di Yayasan Setara)". Skripsi S1. Semarang: Universitas Negeri Semarang

Permen-PPPA N0-8 tahun-2014 tentang Kebijakan Sekolah Ramah Anak

Pora Yusran. 2007. Selamat Tinggal Sekolah. Jakarta: Media Pressindo

Purwanto, Erwan, Agus dan Dyan Ratih, 2012. Implementasi Kebijakan Publik, Konsep dan Aplikasinya di Indonesia, Yogyakarta, Gava Media.
Surakhmad Winarno. 2009. Pendidikan Nasional Strategi dan Tragedi. Jakarta: Kompas Media Nusantara

Utami, Ratnasari Diah dkk. 2017. "Implementasi Penerapan Sekolah Ramah Anak Pada Penyelenggaraan Pendidikan Sekolah Dasar". Journal. Yogyakarta: The Urecol Proceeding

Utari, Ranti Eka. 2016. "Implementasi Program Sekolah Ramah Anak di Sekolah Menengah Pertama Negeri 1 Tempuran Kabupaten Magelang”. Skripsi S1. Yogyakarta: Universitas Negeri Yogyakarta

UU No 11 tahun 2005 tentang pengesahan internasional covenat on economic, social, and cultural rights (Kovenan Internasional tentang hak-hak Ekonomi, Sosial dan Budaya)

UU No 20 tahun 2003 tentang Sistem Pendidikan Nasional

UU No 35 tahun 2014 tentang perubahan atas UU No 23 tahun 2002 tentang Perlindungan anak

Wiyani, Novan Ardi. 2012. Save Our Children From School Bullying. Yogyakarta: Ar-Ruzz Media. 